\title{
Deposition, Endo-drift and Exo-drift in the Pulverization in Coffee With Different Equipment
}

\author{
Tamara Locatelli ${ }^{1}$, Silvério de Paiva Freitas ${ }^{1}$, Ismael Lourenço de Jesus Freitas ${ }^{2}$, Edney Leandro da Vitória ${ }^{2}$, \\ Sávio da Silva Berilli ${ }^{3}$, Sílvio de Jesus Freitas ${ }^{1}$, Silvério de Paiva Freitas Júnior ${ }^{4}$, André Cayô Cavalcanti ${ }^{2}$, \\ Tallita Pedroni Locatelli ${ }^{3}$, Juliana Menegassi Valle ${ }^{2}$, Giacomina Possatti Lepaus ${ }^{3} \&$ Deborah Hoffman Crause $^{2}$ \\ ${ }^{1}$ Laboratory of Plant Science, Center for Agricultural Sciences and Technologies, State University of North \\ Fluminense, Campos, RJ, Brazil \\ ${ }^{2}$ Department of Agrarian and Biological Sciences, Federal University of Espirito Santo, São Mateus, ES, Brazil \\ ${ }^{3}$ Federal Institute of Espírito Santo. Itapina Campus, Colatina, ES, Brazil \\ ${ }^{4}$ Academic Center for Agricultural Sciences and Biodiversity, Federal University of Cariri, Crato, CE, Brazil \\ Correspondence: Tamara Locatelli, Laboratory of Plant Science, Center for Agricultural Sciences and \\ Technologies, State University of North Fluminense, Campos, RJ, Brazil. Tel: 55-(27)-99833-9993. E-mail: \\ tamaralocatelli@gmail.com
}

Received: July 25, $2019 \quad$ Accepted: August 30, $2019 \quad$ Online Published: October 15, 2019

doi:10.5539/jas.v11n17p187 URL: https://doi.org/10.5539/jas.v11n17p187

The research is financed by Higher Education Personnel Improvement Coordination.

\begin{abstract}
The objective was to evaluate the equipment efficiency in reducing drift and increasing the spray deposition. The experiment was conducted of the conilon coffee plantation, located on the experimental area of the Federal Institute of Espirito Santo, Itapina, Brazil. The experiment was a randomized complete block design with four replications. The treatments consisted: a knapsack sprayer with electrostatic assistance, an electric knapsack sprayer, a knapsack sprayer with a spray shield, and a knapsack sprayer without a spray shield. All sprayers were equipped with a single spray nozzle. Spray deposition was evaluated on wee leaves using a food colourant as a tracer. The knapsack sprayer with electrostatic assistance was the most efficient equipment, providing lower values of drift, and the greatest deposition on the weeds. It is recommended to use the electrostatic sprayer, as it showed greater efficiency in the application of the product on the target, using smaller volume
\end{abstract}

Keywords: backpack sprayer, herbicide, knapsack sprayer, weeds

\section{Introduction}

Brazil has been the largest coffee bean producer and exporter since the 19th century, when its production began to be an expressive activity in the economy (Covre, Partelli, Mauri, \& Dias, 2013). Of the 415,000 ha of conilon coffee (Coffea canephora Pierre ex Froehner) in Brazil, 256,550 ha are in Espírito Santo, followed by Rondônia and Bahia with 83,340 and 50,100 ha, respectively (Companhia Nacional de Abastecimento [CONAB], 2018).

Among the factors contributing to a decline in coffee production include coffee competition with weed and coffee injury due herbicide application drift. To reduce herbicide drift, the applicator should use the correct application technology (França et al., 2013; Langaro, Nohatto, Perboni, Tarouco, \& Agostinetto, 2014).

The herbicide application quality can be evaluated by analyzing the deposition, coverage, drift, and control efficacy. However, application droplet size is important in determining application efficiency and effectiveness. Small spray droplets may better cover a plant's surface, but may also evaporate under low relative humidity or be more susceptible wind drift, compared to large spray droplets that may run down a plant for the soil surface (Baesso, Teixeira, Ruas, \& Baesso, 2014).

When the applied product is carried by the wind, instead of reaching the target, it reaches coffee or another area that is not of interest; this phenomenon is known as exo-drift. The loss of product that flows into the soil, whether or not it has been intercepted by the target, is known as endo-drift (Himel, 1969). Endo-drift and 
exo-drift are dependent on the application technology, herbicide formulation, and climatic conditions (Sasaki Sasaki, Teixeira, Fernandes, Monteiro, \& Rodrigues 2013a).

Different equipment such as a Spray shield, an electric sprayer or an electrostatic sprayer can be used in order to reduce drift losses. The electric sprayer ensures greater control of application pressure and application volume (Sasaki, Teixeira, Nogueira, Alvarenga, \& Oliveira, 2013b). The electrostatic sprayer provides a better spray deposition on the target plantsbecause the charged droplet particles tend to adhere to the nearest plant, including the two sides of the sheet (Sasaki et al., 2013a). The spray shield is an alternative method to protect the crop at the time of application, as it directs the spray mixture to the target plants (Christoffoleti \& Nicolai, 2013).

As a result of the problems often caused by application drift, our objective was to determine which equipment provides lower endo-drift (runoff into the soil), minor exo-drift (interception by the coffee tree) and greater deposition of spray mixture on the weeds.

\section{Method}

The experiment was carried out in a conilon coffee plantation (Coffea canephora Pierre ex Froehner), composed of 13 clones Vitória Incaper 8142, located on the Federal Institute of Espirito Santo, Itapina, Brazil. (geographical coordinates: $19^{\circ} 32^{\prime} 22^{\prime \prime}$ south latitude and $40^{\circ} 37^{\prime} 50^{\prime \prime}$ west longitude, at an altitude of $71 \mathrm{~m}$, Municipality of Colatina). The region, with its tropical climate, has a warm and humid summer and a dry winter, and is classified as Aw, according to the classification of Köppen \& Geiger (1928). The experimental units consisted of an area of $12 \mathrm{~m}^{2}(4.0 \times 3.0 \mathrm{~m})$ in a 14-year-old conilon coffee crop during the maturation phase. The plants had an average height of $1.77 \mathrm{~m}$ com spacing of $3.0 \times 1.0 \mathrm{~m}$. Corresponding to a area with 3,333 plants.

A phytosociological survey was performed on the area of coffee plantation, with the objective of characterizing the experimental units, discovering the two most important weed species, Cyperus rotundus and Micranthemum umbrosum. The experiment was conducted using a randomized complete block design distributed in split plot, with four replications, in which spraying equipment was used: knapsack sprayer with electrostatic assistance, a knapsack electric sprayer, and knapsack sprayers with and without a spray shield. The four subplots developed over time corresponded to weed ages, 15, 30, 45 and 60 days after mowing (DAM).

There were four types of equipment: a knapsack sprayer, model SP 20 with a tank capacity of $20 \mathrm{~L}$, a knapsack sprayer, model SP 20 with a tank capacity of 20 L with spray shield,.a knapsack sprayer with electrostatic assistance, model JE8999, with a tank capacity of $18 \mathrm{~L}$, rechargeable battery with $12 \mathrm{~V}$ and $9 \mathrm{Ah}, 35 \mathrm{~W}$ electric pump with $482 \mathrm{kPa}$ and pressure regulation per potentiometer, which uses the pneumatic principle for the formation and fractionation of droplets, in addition to using the indirect charge induction method for the electrification of the drops; and knapsack electric sprayer, model FT-16, with a tank capacity of 16 L, rechargeable battery with $12 \mathrm{~V}$ and $12 \mathrm{Ah}$, with $400 \mathrm{kPa}$ and pressure regulation per potentiometer. The sprayers were equipped with bar with spray flat fan spray tip (TT 11003).

Humidity was measured with a hygrometer. Wind speed, relative humidity and temperature measured for the first application corresponding to 15 days after weeding (15 DAM) were $0.3 \mathrm{~m} \mathrm{~s}^{-1}, 98 \%$ and $37.7^{\circ} \mathrm{C}$, for the second application corresponding to 30 days after weeding (30 DAM) were $1.2 \mathrm{~m} \mathrm{~s}^{-1}, 70 \%$ and $27.3^{\circ} \mathrm{C}$, for the third application corresponding to 45 days after weeding (45 DAM) were $2.1 \mathrm{~m} \mathrm{~s}^{-1}, 68 \%$ and $25.3{ }^{\circ} \mathrm{C}$, and for the fourth aplication corresponding to 60 days after weeding (60 DAM) were $0.2 \mathrm{~m} \mathrm{~s}^{-1}, 98 \%$ and $18.6{ }^{\circ} \mathrm{C}$. The spraying was done in a straight line, in two passes in each plot, in order to cover the entire experimental area, with a displacement of the applicator regulated to $1.0 \mathrm{~m} \mathrm{~s}^{-1}$. The discharge height was $0.50 \mathrm{~m}$.

To evaluate the deposition of spray mix on weed leaves, the runoff onto the soil and the deposition in the leaves of the coffee tree used a tracer composed of dye blue, spraying indicator, at dose of $2 \mathrm{~L}$ ha-1, for absorbance in the spectrophotometer. During the preparation of the spray mixture, a sample was taken to determine the actual or standard concentration of the dye (Palladini, 2000).

The determination of spray mix in weeds was done by collecting weed leaves contained in a wood template 0.20 $\mathrm{m} \times 0.20 \mathrm{~m}$, randomly cast on a single occasion in the experimental plot. Three leaves of Cyperus rotundus and Micranthemum umbrosum in the area were collected. These were then placed separately in plastic jars.

The determination of the drift in the area was performed by randomly distributing soil, just below the weeds, three acetate labels per plot, each with an area of $24 \mathrm{~cm}^{2}$, totaling $72 \mathrm{~cm}^{2}$ of deposited area. After spraying, the labels were collected and placed in plastic bottles.

For the determination of the exo-drift, leaves of the coffee tree were collected at three heights (what were the 3 heights?) and two different depths of the canopy, using a trident-shaped wooden jig. These leaves were collected 
from the four central plants of each plot, two on each side. A coffee leaf was collected at each height and depth, and these were placed in plastic jars.

To accurately quantify the dye that hit the weeds, soil and coffee leaves, the endo-drift, exodrift and deposition values in the weeds were compared with the total spray mixture collected in petri dishes. Petri dishes, which were arranged in the plot above the weeds, to collect $100 \%$ of the spray mixture that was sprayed. After spraying, the plates were collected and placed in plastic bags.

In each of the plastic containers with the coffee leaves and weeds were added $25 \mathrm{ml}$ of distilled water then shaken to extract the dye. The sheets were then removed from the plastic containers, dried with moisture absorbent paper and then stored in plastic bags. In the soil and plant laboratory, Itapina Campus of the IFES, the leaf area of the samples was measured using the LI- $3100^{\circ}$ leaf area meter. After, $25 \mathrm{ml}$ of distilled water was added to the plastic containers containing coffee leaves, weeds and plastic labels. To the bags containing the petri dishes, $50 \mathrm{ml}$ of distilled water was added.

All the samples were analyzed in the Agronomic Laboratory of Soil, Leaf and Water Analysis (LAGRO) at the University Center of North of Espirito Santo of the Federal University of Espírito Santo. The tracer deposition in these samples (coffee leaves, Petri dishes, plastic labels, and weeds) were performed using visible UV spectrophotometry (Reis, Queiroz, Cunha, \& Alves, 2010).

In the laboratory, plastic containers containing distilled water from washing weed samples, plastic labels, coffee leaves and petri dishes were shaken for 30 seconds. The wash liquor from each sample was stored in a test tube, then the absorbance reading of those solutions were measured in a ThermoElectron Corporation ${ }^{\circ}$ spectrophotometer, model Genesys $10 \mathrm{UV}$, set to measure the absorbance at a wavelength of $630 \mathrm{\eta m}$. For this purpose, a $4 \mathrm{~mL}$ aliquot was placed in a glass cuvette for reading in the spectrophotometer.

The absorbance values that were obtained by reading each sample in the spectrophotometer were transformed into concentration $\left(\mathrm{mg} \mathrm{L}^{-1}\right)$ by adopting the standard curve equation established by the dilutions $(1 / 50,1 / 100$, $1 / 200,1 / 500,1 / 1,000,1 / 2,000,1 / 5,000,1 / 10,000,1 / 20,000)$ sample of the sample collected from the spray tank, after application. Knowing the initial spray mixture concentration $\left(10 \mathrm{~mL}^{-1}\right)$ and the volume of dilution of the samples $(25$ and $50 \mathrm{ml}$ ), it was possible to determine the mass of dye retained at the target.

The endo-drift and exo-drift weed deposition data were applied at the $5 \%$ significance level to the Durbin-Watson (DW), Shapiro-Wilk (W) and Bartlett (B) tests to determine the independence of the residues, the normality of residues, and the homogeneity of variances, respectively. While the means of the treatments were matched by the Tukey test, with the interaction of the means tests enabled by using SISVAR statistical software (Ferreira, 2011) at the $5 \%$ level of significance $(\mathrm{p}<0.05)$.

\section{Results and Discussion}

Was verified from the analysis of variance a significant difference among the times of spraying for all collection points. There was also a significant difference among endo-drift treatments. However, there was no significant interaction among the types of equipment and times (weed ages) of spraying for the evaluated variables.

It was verified that, after the treatment splitting corresponding to the types of equipment within the time (weed ages) of spraying, there was no significant difference in the deposition of spray mixture in the Cyperus rotundus weed (WP1) and in the exo-drift (when interception occurred compared to the times of spraying). However, the deposit in the Micranthemum umbrosum weed (WP2) and the endo-drift (soil runoff) was significantly different in relation to the treatments (Table 1). 
Table 1. Average values of spray mixture deposition in the Cyperus rotundus weed plant (WP1) and the Micranthemum umbrosum weed plant (WP2); endo-drift - drainage for soil (ENDO) and exo-drift-interception by the coffee tree $(\mathrm{EXO})$, resulting from the type of equipment being treated within the spraying period (weed age)

\begin{tabular}{|c|c|c|c|c|c|c|c|c|c|}
\hline \multirow[b]{2}{*}{ Treatments } & & \multicolumn{8}{|c|}{ Averages } \\
\hline & & \multicolumn{2}{|l|}{$\begin{array}{l}\text { WP1 } \\
\left(\mu l \mathrm{~cm}^{-2}\right)\end{array}$} & \multicolumn{2}{|l|}{$\begin{array}{l}\text { WP2 } \\
\left(\mu 1 \mathrm{~cm}^{-2}\right)\end{array}$} & \multicolumn{2}{|c|}{$\begin{array}{l}\text { ENDO } \\
\left(\mu 1 \mathrm{~cm}^{-2}\right)\end{array}$} & \multicolumn{2}{|l|}{$\begin{array}{l}\text { EXO } \\
\left(\mu 1 \mathrm{~cm}^{-2}\right)\end{array}$} \\
\hline \multirow{4}{*}{ First spray } & knapsack sprayer with electrostatic assistance & 660.894 & $\mathrm{a}$ & 5.962 & $\mathrm{a}$ & 0.605 & $\mathrm{~b}$ & 704.521 & $\mathrm{a}$ \\
\hline & knapsack electric sprayer & 605.855 & $\mathrm{a}$ & 82.807 & $\mathrm{a}$ & 0.861 & $\mathrm{ab}$ & 717.612 & $\mathrm{a}$ \\
\hline & knapsack sprayer without a spray shield & 947.047 & $\mathrm{a}$ & 97.420 & $\mathrm{a}$ & 1.288 & $\mathrm{a}$ & 995.362 & a \\
\hline & knapsack sprayer with a spray shield & 870.068 & $\mathrm{a}$ & 123.662 & $\mathrm{a}$ & 1.288 & $\mathrm{a}$ & 1031.917 & a \\
\hline \multirow{4}{*}{ Second spray } & knapsack sprayer with electrostatic assistance & 517.910 & $\mathrm{a}$ & 0.470 & a & 0.402 & b & 518.841 & a \\
\hline & knapsack electric sprayer & 192.599 & $\mathrm{a}$ & 0.448 & $\mathrm{a}$ & 0.459 & $\mathrm{ab}$ & 193.735 & a \\
\hline & knapsack sprayer without a spray shield & 460.320 & $\mathrm{a}$ & 0.731 & $\mathrm{a}$ & 0.609 & $\mathrm{ab}$ & 462.320 & $\mathrm{a}$ \\
\hline & knapsack sprayer with a spray shield & 687.761 & $\mathrm{a}$ & 0.789 & $\mathrm{a}$ & 0.800 & $\mathrm{a}$ & 691.571 & $\mathrm{a}$ \\
\hline & knapsack sprayer with electrostatic assistance & 250.031 & $\mathrm{a}$ & 0.785 & $\mathrm{a}$ & 0.145 & b & 169.442 & a \\
\hline \multirow{3}{*}{ Third spray } & knapsack electric sprayer & 233.306 & $\mathrm{a}$ & 1.107 & $\mathrm{a}$ & 0.304 & $\mathrm{ab}$ & 234.959 & $\mathrm{a}$ \\
\hline & knapsack sprayer without a spray shield & 166.927 & $\mathrm{a}$ & 1.703 & $\mathrm{a}$ & 0.371 & $\mathrm{a}$ & 251.282 & $\mathrm{a}$ \\
\hline & knapsack sprayer with a spray shield & 294.111 & $\mathrm{a}$ & 0.622 & $\mathrm{a}$ & 0.456 & a & 295.318 & a \\
\hline \multirow{4}{*}{ Fourth spray } & knapsack sprayer with electrostatic assistance & 931.267 & $\mathrm{a}$ & 262.579 & $\mathrm{a}$ & 0.174 & $\mathrm{a}$ & 1194.152 & $\mathrm{a}$ \\
\hline & knapsack electric sprayer & 1259.463 & $\mathrm{a}$ & 28.659 & $\mathrm{~b}$ & 0.262 & $\mathrm{a}$ & 1288.730 & a \\
\hline & knapsack sprayer without a spray shield & 911.859 & $\mathrm{a}$ & 4.668 & $\mathrm{c}$ & 0.420 & a & 917.223 & $\mathrm{a}$ \\
\hline & knapsack sprayer with a spray shield & 661.836 & $\mathrm{a}$ & 3.769 & $\mathrm{c}$ & 0.256 & $\mathrm{a}$ & 666.023 & $\mathrm{a}$ \\
\hline
\end{tabular}

In the last spray period, the knapsack sprayer with electrostatic assistance was the equipment that provided the largest deposition of the spray mixture to the Micranthemum umbrosum weed, followed by the knapsack electric sprayer. Thus, these two equipment types were the most efficient in depositing a largest amount of spray mixtureon the target weed (Table 1).

According to Baesso et al. (2014), spray droplets can be divided by size: thin $(<200 \mu \mathrm{m})$, medium $(200$ and 400 $\mu \mathrm{m})$ and thick $(>400 \mu \mathrm{m})$. The knapsack sprayer with electrostatic assistance produces thin droplets according to Gitirana Neto, Cunha, Marques, Lasmar, and Borges (2005), which better covers the target and provides greater penetration of the plant canopy (Baesso et al., 2014). Therefore, the droplet size produced by this equipment in the present study indicate a greater efficiency in depositing the spray mixture on the target. Corroborating this result, Cunha, Marques, \& Alves, 2016, demonstrated that the spray tip that generated smaller and more uniform droplets was able to deposit more spray mixture throughout the canopy of soybean plants.

The weed leaf area was greaterr at the 60 DAM application time, due to the greater time following mowing (Figure 1), may have also contributed to a greater deposition by the knapsack sprayer with electrostatic assistance. This result is due to the equipment's ability to deposit of spray mixture to the nearest target, as demonstrated by Sasaki et al. (2013c) and Tavares, Cunha, Alves, Alves, and Silva (2017). In addition, these authors explained that for more distant targets, electrostatic charge loss may occur during the trajectory between the spray tip and the target. 
Cyperus rotundus

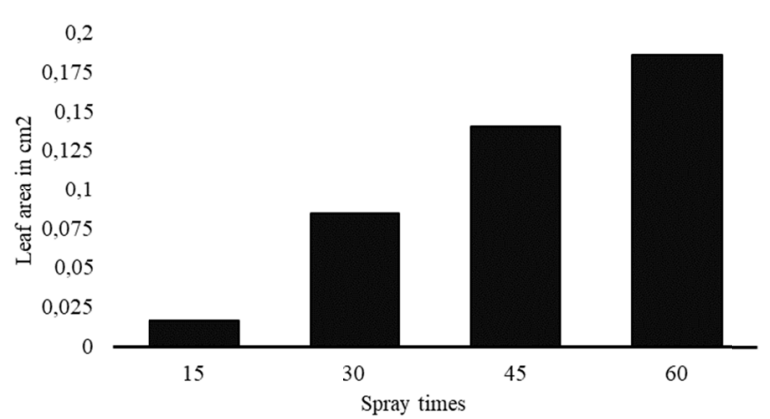

Micranthemum umbrosum

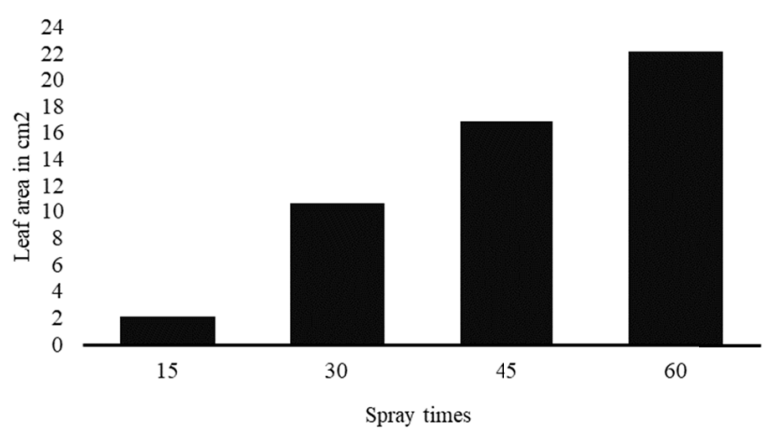

Figure 1. Histograms representing the average area $\left(\mathrm{cm}^{2}\right)$ of Cyperus rotundus and Micranthemum umbrosum weeds at different weed ages, in days after weeding

A third factor that may have influenced the greatest deposit by the knapsack sprayer with electrostatic assistance, as observed in Table 1, was the deposition capacity on both sides of the leaves. According to Chaim (2006), this equipment has the ability to deposit drops on all sides of the grounded body. This characteristic of the sprayer greatly increases the deposition of the spray mix, as demonstrated by Sasaki et al. (2013a), who observed a 37\% increase in the deposition of spray mixture in the canopy of Arabica coffee, when they made use of the electrostatic system, compared to when it was not used.

The lower endo-drift in the first spray occurrences, according to Table 1, could demonstrate the greater efficiency of the knapsack sprayer with electrostatic assistance in relation to knapsack sprayer without a spray shield and knapsack sprayer with a spray shield, since the weeds were still very small, with little leaf area for retaining the spray mix (Figure 1), due to the smaller size, being further away from the spray nozzle. Even so, the loss to the soil was less. This can be explained according to Baesso et al. (2014), because smaller droplets, which better cover the target, have a greater capacity to reach the target and reduce leaf runoff under adequate climatic conditions.

The knapsack sprayer without a spray shield produces larger droplets than the knapsack sprayer with electrostatic assistance and knapsack electric sprayers (Rodrigues, Abi-Saab, Gandolfo, De Oliveira, \& Hasegawa, 2015). Large drops have less problem with evaporation and drift, but have less efficiency in target coverage, as the drops penetrate less into the crop canopy, are heavier and tend to drain easily (Baesso et al., 2014). The knapsack sprayer's with and without spray shield characteristic of producing larger droplets, due to the format of the shield, could explain the greater amount of endo-drift when using this combination of equipment. The shield aims to avoid drifting, which may be detrimental to the coffee plantation, as demonstrated by Maciel, Teixeira, Fernandes, Da Vitória, and Cecon, (2017), who, when evaluating the control of weeds with different herbicides, verified that the drift caused damage to more than $73 \%$ of the aerial part of the castor bean in the treatment without a shield, compared to the treatment when using a shield. Despite this protective feature of the shield, the shield can increase the flow of spray mixture into the soil. In this study, it was possible to observe that when sprayed by the spray tip, the spray mix came into contact with the sides of the accessory and the drops clustered, forming larger drops that would more easily drip when sprayed on the plants.

As to the total spraying destination in the four periods, the knapsack sprayer with electrostatic assistance resulted in a lower endo-drift $(15.26 \%)$, followed by the knapsack electric sprayer $(21.66 \%)$, the knapsack sprayer without a spray shield (30.89\%), and the knapsack sprayer with a spray shield (32.18\%) (Figure 2). 


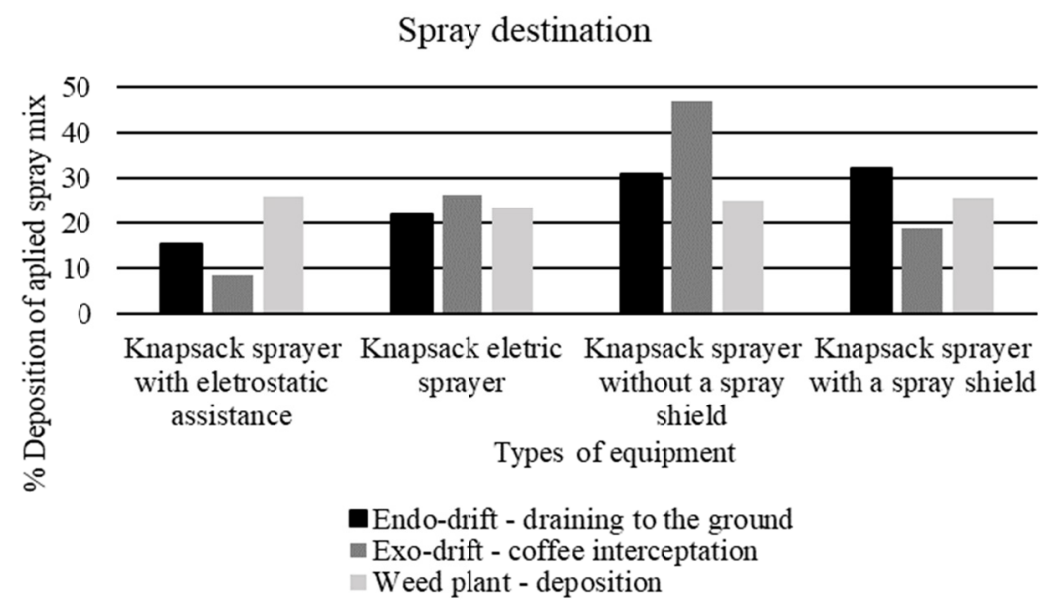

Figure 2. Histograms representing the endo-drift, exo-drift and deposition in the weeds, using different models of sprayers

The lower endo-drift caused by knapsack sprayer with electrostatic assistance and knapsack electric sprayer may be related to the higher working pressure that produces smaller droplets (Fernandes, Parreira, Ferreira, \& Romani, 2007). Maciel et al. (2017), and Cunha et al. (2016) found that, with increasing working pressure, the flow rate also increases, and that the diameter of the produced droplets decreases. Baesso et al. (2014) reported that smaller droplets better cover the target, present a greater capacity to reach the crop, and reduce leaf runoff. The results presented by these authors are similar to those found in the present study, in which the knapsack sprayer with electrostatic assistance offered the best coverage of the target, providing larger spray mix deposit $(25.97 \%)$ in the weeds compared to the other equipment (Figure 2).

The greater endo-drift caused by the knapsack sprayer with a spray shield can be explained by the shape of the shield (Figure 2).

It is also known that the working pressure exerted by the knapsack sprayer with a spray shield, independent of the shield, is lower than that exerted by knapsack electric sprayer and knapsack sprayer with electrostatic assistance (Chaim, 2006). The lower pressure causes the formation of large droplets (Rodrigues et al., 2015), which have a lower capacity to penetrate the crop, increasing the possibility of drainage from the spray mixture into the soil (Baesso et al., 2014). This is probably the reason why the applications made with the knapsack sprayer without a spray shield presented a greater amount of endo-drift (Figure 2).

In addition, the greater flow of spray mixture into the soil facilitated by the equipment, i.e., the knapsack sprayer with a spray shield and the manual knapsack sprayer without spray shield, may be related to the higher volume of spray mixture applied in relation to the other equipment (Figure 3). As demonstrated by Oliveira, Souza Júnior, Pereira, Ruas, and Gdinho Junior (2017), higher sprayer application volumes favored increase spray mixture losses to the soil when spraying carrot plants.

Despite the greater values of endo-drift presented by these two sprayers (the knapsack sprayer with a spray shield and the manual knapsack sprayer without spray shield), after the knapsack sprayer with electrostatic assistance, these were the most efficient in depositing spray mix in the weeds, with a deposit of $25.63 \%$ (knapsack sprayer with a spray shield) and $24.96 \%$ (knapsack sprayer without a spray shield) (Figure 2). This possibly occurred due to the greaterr volume of spray mixture applied by these two types of equipment when compared to the knapsack electric sprayer (Figure 3). 


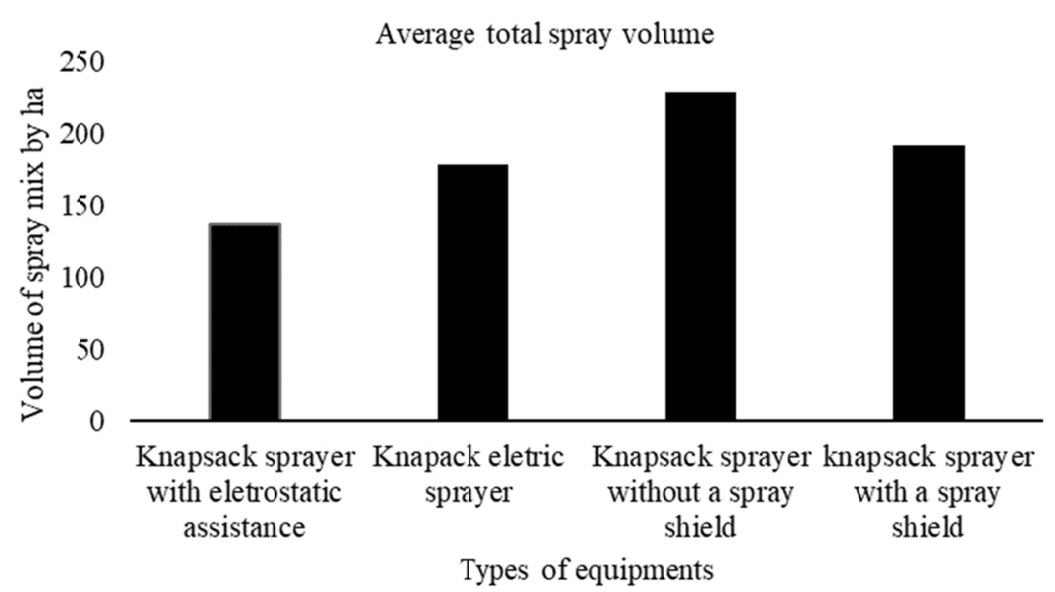

Figure 3. Histogram representing the estimates that express the total volume of spray mixture applied per hectare by the different types of equipment

The knapsack sprayer with electrostatic assistance resulted in a minor amount of exo-drift in the coffee leaves (8.48\%), followed by the knapsack sprayer with a spray shield (18.58\%), the knapsack electric sprayer (26.13\%) and the knapsack sprayer without a spray shield (46.81\%) (Figure 2).

This greater efficiency of the knapsack sprayer with electrostatic assistance, with less exo-drift, has been explained by Chaim (2006), who stated that by adding extra force to the small drops, even when spraying is susceptible to drift, as is the case with electrostatic spraying, the movement of these droplets can be controlled, even against gravity, and droplets with an electrostatic charge can settle on both sides of the leaf.

According to the second law of electrostatics, the charge of a charged body or a cloud of charged particles will induce an equal and opposite electric charge on some nearby grounded conducting body. The attraction force of the charged drop in relation to the plant on both sides of the sheet. The second is a function of the electric field forces of the spray nozzle and the cloud over the electric field of the drop. Thus, if we direct the electric fields to the plant in question, the droplets will project onto it (Chaim, 2006). Therefore, the electrostatic sprayer tends to deposit the spray spray mixture at its closest target, which, in the case of the present study, were weeds, at which the spray tip was directed (Figure 2).

In spite of contributing to a greater flow of spray mixture to the soil, the knapsack sprayer with a spray shield provided good protection for the crop, resulting in the second lowest value of the coffee spray mixture drift (Figure 2). These results are similar to Maciel et al. (2017), who verified the efficiency in protecting the crop, while observing minor damage to castor beans when the shield were used.

Due to the higher working pressure, the knapsack electric sprayer produces smaller droplets, which are easily charged by the wind (Sasaki et al., 2015; Tavares et al., 2017). This explains the second greatest value of exo-drift in coffee leaves and the lower deposition in weeds (23.44\%) in comparison to the knapsack sprayer with electrostatic assistance (25.97\%), which also produces small droplets (Figure 2). The difference is that the droplets expelled by the knapsack sprayer with electrostatic assistance are attracted to the nearest target, due to their electrification (Chaim, 2006). The knapsack electric sprayer ejects the droplets in the direction of the target to which it is directed, and in this trajectory, the small droplets are subject to by wind deviations or evaporation.

The exo-drift in the coffee tree was greater when the knapsack sprayer without a spray shield was used (Figure 2). The most exo-drift using the knapsack sprayer without a spray shield may have been caused by the working pressure of the equipment due to manual pumping. In laboratory resaerch, using different spray tips, flow rates and working pressures, Maciel et al. (2017) showed that, when using the fan-type tip, the flow increased as a result of the increase in working pressure, producing droplets with a smaller diameter. Cunha et al. (2016) found that, with increasing pressure, small droplets formed, with a diameter of less than $100 \mu \mathrm{m}$. A reduction in the droplet diameter occurs because with greater pressure, more liquid is forced across the spray tip, thus, the greater the fractionation of the spray (Maciel et al., 2017). This confirms that the knapsack sprayer provides a greater amount of exo-drift when it is not equipped with the shield. 


\section{Conclusions}

In our research the knapsack sprayer with electrostatic assistance was the most efficient equipment used, allowing for lower endo-drift and exo-drift, as well as depositing a greater amount of product on the weeds with a lower total volume of spray mix applied, which means water concervation, lower production costs, and a lower risk of environmental contamination.

Among all the equipment used, the knapsack sprayer with a spray shield results in a greater amount of endo-drift, while the knapsack sprayer without a spray shield leads to a greater amount of exo-drift and the knapsack electric sprayer deposits a smaller volume of spray mixture on the weeds.

\section{References}

Baesso, M. M., Teixeira, M. M., Ruas, R. A. A., \& Baesso, R. C. E. (2014). Tecnologia de aplicação de agrotóxicos. Revista Ceres, 61, 780-785. https://doi.org/10.1590/0034-737x201461000003

Chaim, A. (2006). Pulverização eletrostática: Principais processos utilizados para eletrificação de gotas. Embrapa Meio Ambiente.

Christoffoleti, P. J., \& Nicolai, M. (2013). Convivência com plantas daninhas não deve limitar cafezal. Visão Agrícola, 12, 37-39.

CONAB (Companhia Nacional de Abastecimento). (2018). Acompanhamento da Safra Brasileira. Café, Segundo Levantamento, Safra 2018. Brasília, Brazil.

Covre, A. M., Partelli, F. L., Mauri, A. L., \& Dias, M. A. (2013). Crescimento e desenvolvimento inicial de genótipos de café Conilon.Agro@mbiente On-line, 7, 193-202.

Cunha, J. P. A. R., Marques, R. S., \& Alves, G. S. (2016). Deposição da calda na cultura da soja em função de diferentes pressões de trabalho e pontas de pulverização. Revista Ceres, 63, 761-768. https://doi.org/ $10.1590 / 0034-737 \times 201663060003$

Fernandes, A. P., Parreira, R. S., Ferreira, M. C., \& Romani, G. N. (2007). Caracterização do perfil de deposição e do diâmetro de gotas e otimização do espaçamento entre bicos na barra de pulverização. Engenharia Agricola, 728-733. https://doi.org/10.1590/S0100-69162007000400016

Ferreira, D. F. (2011). Sisvar: a computer statistical analysis system. Ciência e Agrotecnologia, 35(6), 1039-1042.

França, A. A. C., Carvalho, F. P., Fialho, C. M. T., D’Antonino, L., Silva, A. A. A., Santos, J. B., \& Ferreira, L. R. (2013). Deriva Simulada do Glyphosate em cultivares de café acaiá e catucaí. Planta Daninha, 31, 443-151. https://doi.org/10.1590/S0100-83582013000200023

Gitirana Neto, J., Cunha, J. P. A. R., Marques, R. S., Lasmar, O., \& Borges, E. B. (2015). Deposição de calda promovida por pulverizadores empregados na cafeicultura de montanha. Coffee Science, 11, 276-275.

Himel, C. M. (1969). The optimum size for insecticide spray droplets. Journal of Economic Entomology, 62, 919-925. https://doi.org/10.1520/STP104310

Köppen, W., \& Geiger, R. (1928). Klimate der Erde. Gotha: Verlag Justus Perthes. Wall-map 150cmx200cm.

Langaro, A. C., Nohatto, M. A., Perboni, L. T., Tarouco, C. P., \& Agostinetto, D. (2014). Alterações fisiológicas na cultura do tomateiro devido à deriva simulada de herbicidas. Revista Brasileira de Herbicidas, 13, 40-46. https://doi.org/10.7824/rbh.v13i1.282

Maciel, C. D. G., Poletine, J. P., Velini, E. D., Amaral, J. G. C., Zani, L. P., Santos, R. F., ... Ribeiro, R. B. (2008). Possibilidade de aplicação de misturas de herbicidas de ação total com jato dirigido em mamoneira de porte anão. Planta Daninha, 26, 457-464. https://doi.org/10.1590/S0100-83582008000200023

Maciel, C. F. S., Teixeira, M. M., Fernandes, H. C., Da Vitória, E. L., \& Cecon, P. R. (2017). Distribuição volumétrica e espectro de gotas das pontas hidráulicas LD 11002 e MAG-2. Revista de Engenharia na Agricultura, 25, 183-199. https://doi.org/10.13083/reveng.v25i3.671

Miranda, G. R. B., Raetano, C. G., Cunha, M. D. Q., Pinheiro, J. M., Lopes, P. R., Prado, A. S., ... Gonçalves, M. P. (2013). Equipamentos de pulverização associados a volumes de calda e avaliados por alvos artificias em cafeeiro. Revista Agrarian, 6, 448-459.

Oliveira, V. B. M., Souza Júnior, J. M, Pereira, L. O. A., Ruas, R. A. A., \& Gdinho Junior, J. D. (2017). Análise de deposição e penetração de calda na cultura da cenoura. Global Science and Technology, 10, 121-127. 
Palladini, L. A. (2000). Metodologia para avaliação da deposição em pulverizações (Tese de Doutorado, Universidade Estadual Paulista, Botucatu, São Paulo).

Reis, E. F., Queiroz, D. M., Cunha, J. P. A. R., \& Alves, S. M. F. (2010). Qualidade da aplicação aérea líquida com uma aeronave agrícola experimental na cultura da soja (Glycine max L.). Engenharia Agrícola, 30, 958-966. https://doi.org/10.1590/S0100-69162010000500017

Rodrigues, E. B., Abi-Saab, O. J., Gandolfo, M. A., de Oliveira, R. B., \& Hasegawa, M. M. (2015). Deriva de equipamentos costais na aplicação de glyphosate. Revista Brasileira de Engenharia Agrícola e Ambiental-Agriambi, 19, 1012-1017. https://doi.org/10.1590/1807-1929/agriambi.v19n10p1012-1017

Sasaki, R. S., Teixeira M. M., Santiago, H., Madureira, R. P., Maciel, C. F. S., \& Fernandes, H. C. (2015). Adjuvantes nas propriedades físicas da calda, espectro e eficiência de eletrificação das gotas utilizando a pulverização eletrostática. Ciência Rural, 45, 274-279. https://doi.org/10.1590/0103-8478cr20131604

Sasaki, R. S., Teixeira, M. M., Fernandes, H. C., Monteiro, P. M. B., \& Rodrigues, D. E. (2013a). Deposição e uniformidade de distribuição de calda de aplicação em plantas de café utilizando a pulverização eletrostática. Ciência Rural, 43, 1605-1609. https://doi.org/10.1590/S0103-84782013000900011

Sasaki, R. S., Teixeira, M. M., Fernandes, H. C., Monteiro, P. M. B., Rodrigues, D. E., \& Alvarenga, C. B. (2013c). Parameters of electrostatics praying and its influence on the application efficiency. Revista Ceres, 60, 474-479. https://doi.org/10.1590/S0034-737X2013000400005

Sasaki, R. S., Teixeira, M. M., Nogueira, L. E., Alvarenga, C. B., \& Oliveira, M. V. M. (2013b). Desempenho operacional de um pulverizador costal elétrico. Pesquisa Agropecuária Tropical, 43, $339-342$. https://doi.org/10.1590/S1983-4063201300030001

Tavares, R. M., Cunha, J. P. A. R., Alves, T. C., Alves, G. S., \& Silva, J. E. R. (2017). Estudo de um sistema de eletrificação de gotas em pulverizador costal pneumático pelo método de gaiola de Faraday. Revista Ceres, 64, 476-485. https://doi.org/10.1590/0034-737x201764050004

\section{Copyrights}

Copyright for this article is retained by the author(s), with first publication rights granted to the journal.

This is an open-access article distributed under the terms and conditions of the Creative Commons Attribution license (http://creativecommons.org/licenses/by/4.0/). 